\title{
Voting Premium in Italy: An Analysis over a 30-Year Period
}

\author{
Antonio Salvi ${ }^{1}$, Emanuele Teti ${ }^{2}$, Anastasia Giakoumelou ${ }^{1} \&$ Felice Petruzzella $^{1}$ \\ ${ }^{1}$ Bocconi University and SDA Bocconi School of Management, Italy \\ ${ }^{2}$ University of Pisa, Italy \\ Correspondence: Emanuele Teti, University of Pisa, Italy. E-mail: emanuele.teti@sdabocconi.it
}

Received: September 13, 2018

Accepted: November 28, 2018

Online Published: December 31, 2018

doi:10.5539/ijbm.v14n1p206

URL: https://doi.org/10.5539/ijbm.v14n1p206

\begin{abstract}
We investigate the different aspects affecting the control premium by carrying out an empirical analysis on the respective in the Italian stock market since 1987 employing the Voting Premium methodology. We demonstrate how the introduction of new regulations in this field in 2012 has contributed to a substantial premium reduction. The impact of the aforementioned regulations needs to be examined within the macroeconomic setting that has distinguished the period of reference, particularly the last decade, within which the decision to raise the tax rate on financial yields needs to be contextualized.
\end{abstract}

Keywords: Control premium, corporate finance, voting premium

\section{Introduction}

The terminology of control premium was introduced in the eighties, when it was necessary to highlight the differential between prices negotiated in the stock market and prices offered for Mergers and Acquisitions (M\&As). The so-called price for the control package should, thus, reflect the ability of firms to generate cash flows in their as-is condition. The difference of the price offered to the holder at the stage of acquisition of a majority package versus the price of minority stakes comprises the "acquisition price" that includes, in addition to potential internal improvements and synergies achievable, the "pure premium" for control obtainable by majority shareholders to the detriment of minority shareholders, allowing the former to pursue interests in corporate management more appropriable by them. Therefore, the acquiring firm appears willing to pay an acquisition premium if it is considered able to improve the target company through the operation with ameliorative actions - e.g.: a radical management change, implementation of economies of scale, synergies, etc. - which can increase value and bring profitability to the new ownership basis.

The maximum price that an investor is willing to pay for the acquisition of a percentage of the share capital, able to ensure control over the target, can be calculated as follows:

$$
V_{A}=\left(V_{\text {basis }}+V_{\text {div }}\right) * x+V_{\text {ind }}
$$

where:

$$
\begin{aligned}
& V_{A}=\text { final value of the control package } \\
& V_{\text {basis }}=\text { basis value (as-is) of the target company } \\
& V_{\text {div }}=\text { value of divisible benefits } \\
& V_{\text {ind }}=\text { value of indivisible benefits } \\
& X=\text { percentage of the share capital subject to acquisition }
\end{aligned}
$$

It is clear that divisible benefits and the basis value of the target company affect the final value of the latter in a proportionate manner, depending on the stake subject to negotiation. Contrariwise, the value of indivisible synergies is a constant value that is added up, without any dilutive effect.

When discussing about control premium it is also very important to account for the type of ownership structure underlying the target company as the percentage of share capital required to assume control over it may vary significantly. In fact, in case the shareholding of the target company is particularly widespread, a stake inferior to $50.1 \%$ is sufficient to ensure the de facto control of the company.

The Shapley Value - that is, a ratio that highlights the number of times a player in a game is fundamental for the 
outcome of the same game, is a very important measurement indicator. It is calculated as follows:

$$
\mathrm{VS}_{\mathrm{i}}=\frac{n_{i}^{\text {Pivotal }}}{n !}
$$

As can be seen on the basis of this intuition, the higher the value of the ratio, the higher the influence that the $i^{\text {th }}$ player can exert.

This paper aims at investigating the different aspects affecting the control premium by carrying out an empirical analysis on the respective in the Italian stock market since 1987 employing the Voting Premium methodology. We analyse an exhaustive sample over a 30-year period that spans from 1987 to 2017 . This choice has been made considering previous studies in the field and trying to bridge the gap within existing literature that focuses on limited timeframes of analysis. Due to the new fiscal legislation effective since January 1, 2012 that provides for a $20 \%$ tax on shares, we have decided to include a dummy variable in our model able to capture any potential effect of this legislative change on the estimation of the control premium in the Italian market. We demonstrate how the introduction of new regulations in this field in 2012 has contributed to a substantial premium reduction. The paper is structured as follows: section 2 reviews the reference literature, section 3 presents the methods, data and techniques used in the research. Section 4 presents the results while a final section ends the paper.

\section{Literature Review}

The two main strands of financial literature in the field are differentiated between them by focusing on the two main methodologies of estimation of the control premium - that of control block premium and that of Voting Premium.

The method regarding Control Block Premium, according to Barclay and Holderness (1989; 1991), is based on the estimation of the premium offered by acquirers in order to compensate the selling shareholders for private benefits that they, by acquiring the controlling block of shares, are able to exploit to their own advantage. The same scholars, in fact, suggest to verify the price difference between the price offered for the acquisition of a controlling block of shares and the market price of the same shares after the acquisition announcement. In this way, if we assume markets are efficient, the market will have incorporated potential economic and financial benefits brought in by the new ownership (divisible benefits) into the evaluation of the share price, while, at that point, any persisting difference between market price post-announcement and acquisition price will reflect an estimation of what literature identifies as indivisible benefits.

Accordingly we can state that:

$$
\operatorname{PrS}=\frac{\left(P_{\text {con }}-P_{\text {post }}\right) x N_{b}}{P_{\text {post }} x N_{t}}
$$

Dove:

$$
\begin{aligned}
& \operatorname{Pr} S=\text { standardized premium expressed as a capitalization } \% \\
& P_{c o n}=\text { negotiation price of the control package } \\
& P_{\text {post }}=\text { market price of the announcement of control exchange } \\
& N_{b}=\text { number of shares included in the control package } \\
& N_{t}=\text { overall number of outstanding shares }
\end{aligned}
$$

Despite these preliminary remarks, Barclay and Holdernerss (1989) come to the conclusion that, even considering the post-announcement share price, a premium underestimation may still be possible, as part of the payment could be kept reserved and the negotiation of the shareholding block does not necessarily imply a control transfer. From the study conducted it would emerge that single investors tend to exercise a larger control and, thus, appropriate of private benefits to a larger extent, especially when dealing with the acquisition of very leveraged target companies.

Another important contribution on the Control Block Premium methodology has been produced by Caprio, Floreani and Redaelli (1994) that, following the previous study, highlight and pay attention to the "residual overprice once the Stock Exchange has fully discounted the effect of control change". Based on an ex post analysis, an average percentage overprice equal to $40.6 \%$ is obtained with a median of $32.2 \%$.

Other particularly important studies on the topic are those of Nicodano and Sembenelli (2004), Dyck and 
Zingales (2004), Massari, Monge and Zanetti (2006). Following the aforementioned research works, it is possible to observe that any estimation of the premium may greatly vary different depending on the timeframe applied and type of sample employed. To corroborate such notion, the reference market appears to also generate a relevant impact as can be noticed in the study conducted by Dick and Zingales (2004) where premium results univocal.

What emerges from the key studies concerning the Control Block Premium is that the premium estimation is strongly linked to the type of transaction (transaction-specific). More specifically, factors such as the target firm's characteristics, in terms of typology and industry sector, as well as the size of the shareholding block subject to negotiations, are central in the analysis. Following, Table 1 summarizes the main academic findings on Control Block Premium.

Table 1. Main Literature on control block premium

\begin{tabular}{|c|c|c|c|c|c|c|}
\hline Author & year & Journal & Typology of negotiation and shares & $\begin{array}{l}\text { Sample } \\
\text { width }\end{array}$ & Period & $\begin{array}{l}\text { Average } \\
\text { Premium }\end{array}$ \\
\hline $\begin{array}{l}\text { Caprio, Floreani, } \\
\text { Radaelli }\end{array}$ & 1994 & $\begin{array}{l}\text { Finanza Imprese e } \\
\text { Mercati }\end{array}$ & Transactions $>50 \%$ of capital & 33 & $\begin{array}{c}1982- \\
1992\end{array}$ & $22,5 \%$ \\
\hline $\begin{array}{l}\text { Nicodano and } \\
\text { Sembenelli }\end{array}$ & 2004 & $\begin{array}{l}\text { International Review of } \\
\text { Financial Analysis }\end{array}$ & $\begin{array}{l}46 \text { Transactions }<10 \% \text { of capital } 48 \\
\text { Transactions }>10 \% \text { of capital }\end{array}$ & 94 & $\begin{array}{c}1987- \\
1982\end{array}$ & $\begin{array}{c}27 \% \mathrm{e} \\
19 \%\end{array}$ \\
\hline $\begin{array}{l}\text { Dick and } \\
\text { Zingales }\end{array}$ & 2004 & Journal of Finance & $\begin{array}{l}\text { Block packages }>10 \% \text { of capital after } \\
\text { which the total of capital owned is }>20 \%\end{array}$ & 8 & $\begin{array}{c}1990- \\
2000\end{array}$ & $37 \%$ \\
\hline $\begin{array}{l}\text { Massari, Monge } \\
\text { and Zanetti }\end{array}$ & 2006 & $\begin{array}{l}\text { Journal of Management } \\
\text { and Governance }\end{array}$ & $\begin{array}{l}\text { Block packages; Block packages }+ \\
\text { Takeover bid; Takeover bid }\end{array}$ & 27 & $\begin{array}{c}1993- \\
2003\end{array}$ & $8 \%$ \\
\hline
\end{tabular}

As can be seen from Table 1 and previously mentioned, the premium estimation varies depending on the observation period and the type of sample used in the study. Additionally, what makes premium even more univocal is the reference market of the study.

The Voting Premium methodology, on the other hand, focuses on the voting rights attached to shares as the source due to which investors can exercise their will and occasionally also control during shareholders' meetings. This methodology bases its estimation of the premium on the difference observed between common shares' price and that of shares with limited or null voting rights. Such price differential constitutes a proxy for the premium that shareholders pay in order to exercise the underlying voting rights and the eventual possibility of obtaining corporate control through sufficient voting rights.

At this point it is worth noting that relevant legislation varies greatly globally. As a matter of fact, several countries allow for multiple categories of saving shares that incorporate different voting rights. In Italy, the main market of reference for this study, saving shares do not include voting rights compensated through an increased dividend.

The principal reasons behind the existence of a price differential between the two categories of shares involve:

- Company's degree of competitiveness: the lower its ownership concentration, the higher the probability a change of control takes place;

- $\quad$ Dividend differential between saving shares and common shares: the higher such differential, the lower the price difference;

- Level of private benefits for control: the larger the possibility to appropriate private benefits deriving from control, the more the price offered for common shares tends to increase.

- Liquidity differential: in case of low liquidity of shares that incorporate voting rights present, investors will require a higher liquidity premium that, in turn, increases the price differential between the two categories of stock.

The key literature findings with respect to the italian market as far as the Voting premium methodology is concerned are to be found in the works of Zingales (1994), Nicodano (1998), Linciano (2002), Venanzi (2003), Caprio and Croci (2008). Table 2 summarizes the aforementioned academic works in the field. 
Table 2. Main Literature on voting premium

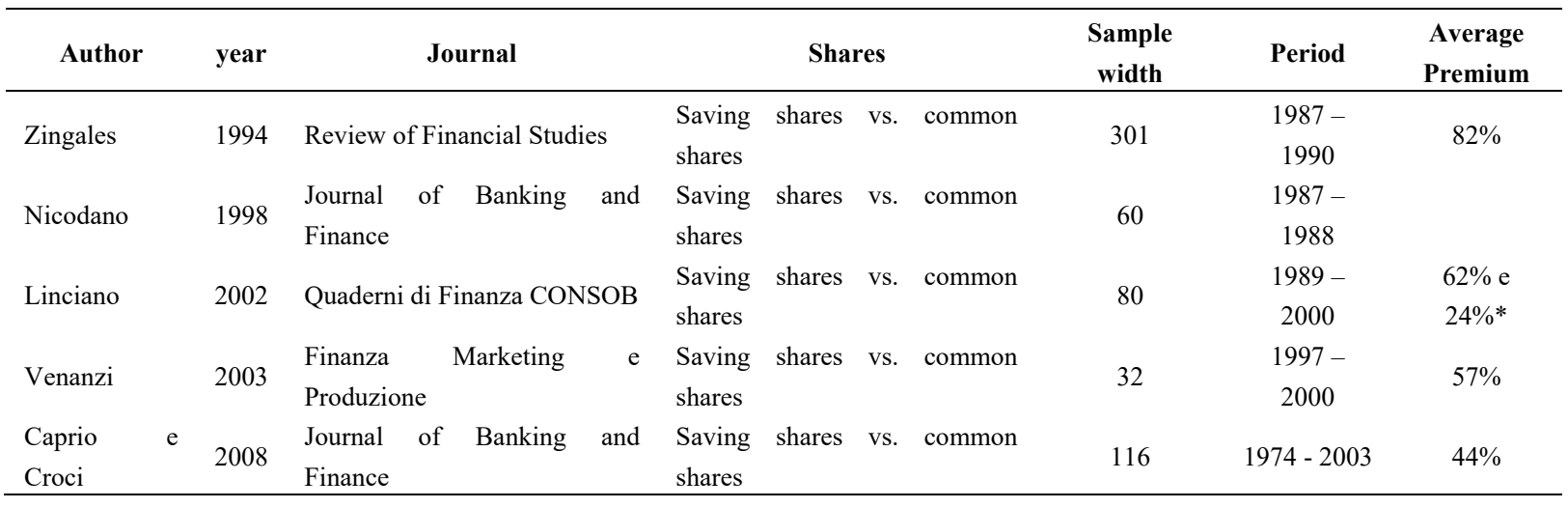

*total voting premium and voting premium respectively

Source: Premi per il controllo, metodo, misure, evidenze (Antonio Salvi, 2013), page 65

It must be stressed the specific scenario in which the analysis has been conducted and the correlated regulatory context. The new regulations implemented in 2012 have provided for the increase of withholding tax on stocks from 12.5 to 20 per cent, and in 2014 with the subsequent increase of the same from 20 to 26 per cent.

\section{Methods and Techniques}

The main hypothesis the paper aims at testing is the following one:

HP: the introduction of new regulations in 2012 and further regulations in 2014, referring to tax issues changes have contributed to a substantial premium reduction.

To this end, we analyse an exhaustive sample over a 30-year period that spans from 1987 to 2017. This choice has been made considering previous studies in the field and trying to bridge the gap within existing literature that focuses on limited timeframes of analysis. Furthermore, due to the new fiscal legislation effective since January 1,2012 that provides for a $20 \%$ tax on shares, we have decided to include a dummy variable in our model able to capture any potential effect of this legislative change on the estimation of the control premium in the Italian market. What is more, as the taxation has moved from $20 \%$ to $26 \%$ since July 1,2014 , we have employed an additional dummy variable able to account for the potential effects of such change on the premium. Therefore, not only do we aim to analyse the trend of Voting Premium over a time span of thirty years, but we also make an attempt to verify how and whether the introduction of the aforementioned new legislations has affected the premium estimation.

Data on prices of common and saving shares listed in the Italian Stock Exchange have been drawn from the Datastream database. We also consulted the annual report "Indici e Dati" published by Mediobanca, where key information on listed companies and characteristics of the Securities issued by them is summarized. By crossing this data with our data on shares obtained by Datastream, it has been possible to rebuild a sample of companies in which both prices of common shares and those of saving shares were indicated on a yearly basis.

The Voting premium has been computed as an average of end prices observed, considering negotiations ten days prior to the $30^{\text {th }}$ June of each year and 10 days after the same date. The methodology used for the estimation of the price is the one first introduced by Zingales (2014):

$$
\mathrm{VP}=\frac{P_{\text {com }}-P_{\text {sav }}}{P_{\text {sav }}}
$$

Where:

$$
\begin{aligned}
& P_{\text {com }}=\text { price of common shares } \\
& P_{\text {sav }}=\text { price of saving shares }
\end{aligned}
$$

We collected our data on the number of common and saving shares issued consulting the annual dossier "Calepino Dell'Azionista" that Mediobanca publishes every October. Data available in this document have further made it possible to identify the type of the main shareholder, considering, in particular, certain categories such as State, Family and Foreign Investor. As for data of the financial statements such as financial leverage (Net financial debt/Total Assets) regarding the companies composing our sample, we have used the Worldscope 
database. Finally, in order to obtain data referring to the yield rates of the 10-year government bonds, we once more used the Datastream database.

We operationalise the main variables included in the regression model as follows:

- Voting Premium: It represents the dependent variable of the model and is calculated as the difference between the price of common shares and that of saving shares, over the price of saving shares.

- Voting ratio: It is the ratio between the amount of saving shares and common shares. It represents an expression of the separation between ownership and control. An increase of this ratio is expected to produce a positive effect on premium, as control is concentrated in a lower number of shares with voting rights leading to an increase of the price differential, due to the resulting higher value attributed to common shares.

- Leverage: It is calculated as the ratio between total debt and total assets. Should this ratio increase, a negative impact on premium is to be expected as the differential between common shares and saving shares will decrease as a result of the lower value attributed to the company's control.

- Fiscal Treatment, 1995: This variable considers the regulations in terms of different taxation policies introduced on January, 1, 1995, which have contributed to decrease the tax burden on dividends of shares. The dummy variable assumes a value of 1 up to 1994 and 0 for any year after that. The lower tax burden is expected to generate a positive impact on control premium and, therefore, the variable is expected to produce a negative impact on premium estimation.

- Fiscal Treatment 2012: The variable assumes a value of 1 from 2012 to 2014 with the aim to highlight the potential effects of the tax rate change put into force on July 1, 2012. The expected impact on premium is negative.

- Fiscal Treatment 2014: The variable assumes a value of 1 from 2015 to 2017, as it intends to estimate the potential effects on premium generated by the introduction of tax regulations on financial asset yields. This treatment came into force on July 1, 2014 and provided for a tax rate increase from $20 \%$ to $25 \%$. The expected impact on premium is negative.

- Law 1992: The variable assumes a value of 1 from 1992 to 1997 and has the aim to identify the potential effects on premium due to new regulations concerning Takeover Bids. The expected impact on premium is positive.

- Law 1998: The variable assumes a value of 1 for years after 1998 and has the aim to record the potential effects on premium due to the new regulations introduced with the Testo Unico della Finanza (TUF). The expected impact of this variable on premium is negative due to the larger protection provided to minority shareholders and to stricter regulations restraining the appropriation of private benefits for majority shareholders.

- State: It is a dummy variable with a value of 1 if the main shareholder is the State. The expected effect on premium is negative, since State-owned companies have a low probability to incur a management change of control.

- Family: It is a dummy variable with a value of 1 if the main shareholder is a family or a single person. The effect on premium is expected to be negative as family-owned companies hardly allow third parties to step in and assume control. As a consequence, low probability of a management change of control is expected to reduce premium.

- Foreign: It is a dummy variable with a value of 1 if the main shareholder is a foreigner. The expected effect on the premium is negative, since countries which foreign investors belong to enjoy an average or low protection compared to the Italian legal framework with such respect.

- BTP $10 Y$ Yield: It represents the expected yield of the long-term government bonds (10 years). The expected impact on the premium is positive since the saving shares could be considered as a safe investment alternative and, thus, be comparable to government bonds. An increase of the yield of government bonds is expected to lead to a decrease in the saving shares price and, thus, a rise in the expected yield of the investment. The latter would lead to an increase in the price differential between the two categories of shares, and thus the premium.

\section{Results}

Table 3 provides an overview of our sample and its main descriptive statistics. 
Table 3. Descriptive statistics of the sample

\begin{tabular}{|c|c|c|c|c|c|c|}
\hline year & Observations & VP average & VP median & Family & $\begin{array}{l}\text { Foreign } \\
\text { investor }\end{array}$ & State \\
\hline 1987 & 35 & $69.93 \%$ & $70.50 \%$ & 16 & 1 & 3 \\
\hline 1988 & 42 & $94.25 \%$ & $104.15 \%$ & 17 & 2 & 3 \\
\hline 1989 & 42 & $88.80 \%$ & $89.40 \%$ & 18 & 2 & 2 \\
\hline 1990 & 49 & $62.47 \%$ & $55.93 \%$ & 18 & 1 & 1 \\
\hline 1991 & 43 & $59.09 \%$ & $67.48 \%$ & 15 & 1 & 2 \\
\hline 1992 & 59 & $78.26 \%$ & $65.54 \%$ & 24 & 7 & 5 \\
\hline 1993 & 48 & $66.05 \%$ & $46.53 \%$ & 26 & 2 & 2 \\
\hline 1994 & 47 & $59.23 \%$ & $62.37 \%$ & 18 & 5 & 3 \\
\hline 1995 & 50 & $71.20 \%$ & $67.55 \%$ & 17 & 4 & 4 \\
\hline 1996 & 47 & $69.21 \%$ & $73.39 \%$ & 17 & 2 & 5 \\
\hline 1997 & 41 & $56.82 \%$ & $60.44 \%$ & 15 & 3 & 4 \\
\hline 1998 & 39 & $47.48 \%$ & $46.64 \%$ & 13 & 4 & 3 \\
\hline 1999 & 44 & $39.74 \%$ & $30.09 \%$ & 18 & 6 & 0 \\
\hline 2000 & 45 & $58 \%$ & $42.63 \%$ & 20 & 6 & 1 \\
\hline 2001 & 37 & $31.32 \%$ & $21.51 \%$ & 16 & 7 & 1 \\
\hline 2002 & 34 & $18.53 \%$ & $8.80 \%$ & 17 & 4 & 1 \\
\hline 2003 & 18 & $15.13 \%$ & $6.30 \%$ & 10 & 2 & 0 \\
\hline 2004 & 27 & $19.94 \%$ & $12.04 \%$ & 12 & 2 & 1 \\
\hline 2005 & 27 & $12.08 \%$ & $6.90 \%$ & 14 & 2 & 1 \\
\hline 2006 & 24 & $6.08 \%$ & $2.72 \%$ & 11 & 4 & 0 \\
\hline 2007 & 24 & $7.44 \%$ & $6.30 \%$ & 14 & 2 & 0 \\
\hline 2008 & 23 & $9.33 \%$ & $4.02 \%$ & 15 & 1 & 2 \\
\hline 2009 & 24 & $4.48 \%$ & $3.54 \%$ & 15 & 2 & 2 \\
\hline 2010 & 24 & $3.08 \%$ & $1.99 \%$ & 16 & 1 & 2 \\
\hline 2011 & 24 & $19.95 \%$ & $19.01 \%$ & 13 & 1 & 2 \\
\hline 2012 & 22 & $12.34 \%$ & $12.18 \%$ & 11 & 1 & 2 \\
\hline 2013 & 14 & $-16.71 \%$ & $-69.94 \%$ & 6 & 0 & 1 \\
\hline 2014 & 10 & $-36.23 \%$ & $-57.27 \%$ & 4 & 0 & 1 \\
\hline 2015 & 12 & $22.03 \%$ & $19.91 \%$ & 7 & 2 & 0 \\
\hline 2016 & 12 & $-11.05 \%$ & $-3.19 \%$ & 8 & 2 & 0 \\
\hline 2017 & 9 & $-0.46 \%$ & $15.63 \%$ & 5 & 3 & 0 \\
\hline
\end{tabular}

Given that the analysed sample is made up of Italian companies, it emerges that families in the role of the main shareholder are recurrent in the corporate structure of the underlying firms. We can also observe that the estimation of the control premium varies considerably over the period analysed. 


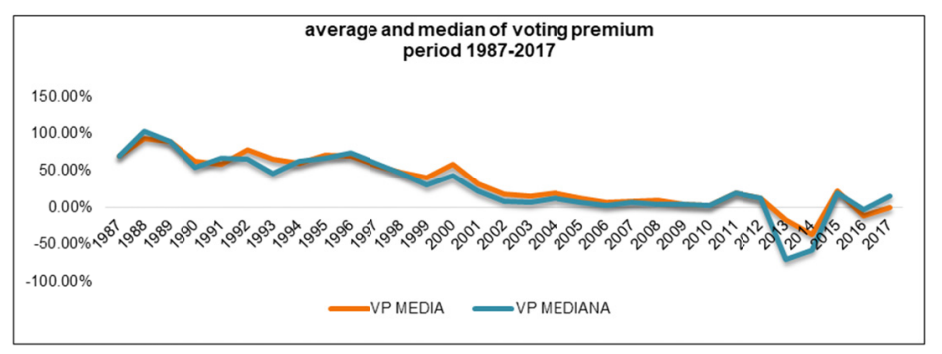

Figure 1. Average and median of voting premium (1987-2017)

Subsequently, Figure 1 depicts the trend recorded over our 30-year analysis, in terms of mean and median of the Voting Premium. We can further notice how the value of the premium has fluctuated between positive and negative values during the last year. It is worth noting that starting 2014 the number of companies in our sample has significantly decreased introducing a potential bias in the estimation process.

Since 1986 control premia have followed a downward trend, in the same manner the number of companies with saving shares have. For this reason we have decided to report a summarizing table highlighting, for each year, the number of firms with non-convertible saving shares as from Mediobanca's report, and the number of firms belonging to the examined sample. From Table 4, it indeed emerges how since 1992 the number of companies issuing saving shares has constantly decreased.

Table 4. Firms with outstanding non-convertible saving shares VS sample firms

\begin{tabular}{|c|c|c|c|}
\hline year & $\begin{array}{l}\text { Firm with outstanding saving shares, non-convertible } \\
\text { (indexes and data Mediobanca) }\end{array}$ & $\begin{array}{l}\text { Sample firms } \\
\text { (Datastream) }\end{array}$ & Delta \\
\hline 1987 & 75 & 35 & -40 \\
\hline 1988 & 87 & 42 & -45 \\
\hline 1989 & 87 & 42 & -45 \\
\hline 1990 & 95 & 48 & -46 \\
\hline 1991 & 99 & 43 & -56 \\
\hline 1992 & 101 & 59 & -42 \\
\hline 1993 & 97 & 48 & -49 \\
\hline 1994 & 90 & 47 & -43 \\
\hline 1995 & 85 & 50 & -35 \\
\hline 1996 & 79 & 47 & -32 \\
\hline 1997 & 75 & 41 & -34 \\
\hline 1998 & 67 & 39 & -28 \\
\hline 1999 & 66 & 44 & -22 \\
\hline 2000 & 61 & 45 & -16 \\
\hline 2001 & 51 & 37 & -14 \\
\hline 2002 & 51 & 34 & -17 \\
\hline 2003 & 47 & 18 & -29 \\
\hline 2004 & 40 & 27 & -13 \\
\hline 2005 & 37 & 27 & -10 \\
\hline 2006 & 34 & 24 & -10 \\
\hline 2007 & 32 & 24 & -8 \\
\hline 2008 & 31 & 23 & -8 \\
\hline 2009 & 31 & 24 & -7 \\
\hline 2010 & 31 & 24 & -7 \\
\hline 2011 & 31 & 24 & -7 \\
\hline 2012 & 29 & 22 & -7 \\
\hline 2013 & 29 & 14 & -15 \\
\hline 2014 & 23 & 10 & -13 \\
\hline 2015 & 20 & 12 & -8 \\
\hline 2016 & 18 & 12 & -16 \\
\hline 2017 & 16 & 9 & -7 \\
\hline
\end{tabular}


We conduct a regression analysis following three different methodologies. The first consists of simple or pooling regression where observations have been analysed as a whole without any particular precaution. The remaining two methodologies, instead, follow a Panel rationale. In this case, our sample's data are organized in time series, suitable for the estimation of the control premium over thirty years, and in cross sections, given that each year's observations belong to a different set of firms. For each of the latter we do not only exhibit the estimation of Voting Premium, but also a series of parameters already explained through the variables of the model previously presented.

To establish whether a Random Effects or a Fixed Effects model should be applied on our analysis, we conducted the Hausman test that suggested the Random Effects model was a better fit. However, for the sake of completeness of our work and given that findings do not differ substantially, we also hereafter report the results obtained with all three models, also to emphasize any potential differences.

Table 5. Findings of the 3 regression models

\begin{tabular}{|c|c|c|c|}
\hline & (1) & (2) & (3) \\
\hline VARIABLES & OLS & Fixed Effects & Random Effects \\
\hline \multirow[t]{2}{*}{ VOTING_RATIO } & $0.860 * * *$ & $0.826 * * *$ & $0.837 * * *$ \\
\hline & $(0.150)$ & $(0.272)$ & $(0.249)$ \\
\hline \multirow[t]{2}{*}{ L92 } & 0.0125 & 0.0338 & 0.0298 \\
\hline & $(0.107)$ & $(0.0975)$ & $(0.0978)$ \\
\hline \multirow[t]{2}{*}{ L98 } & -0.190 & -0.189 & $-0.191 *$ \\
\hline & $(0.132)$ & $(0.115)$ & $(0.115)$ \\
\hline \multirow[t]{2}{*}{ FISC_TREAT_95 } & 0.000673 & -0.0478 & -0.0438 \\
\hline & $(0.0879)$ & $(0.0682)$ & $(0.0682)$ \\
\hline \multirow[t]{2}{*}{ FISC_TREAT_2012 } & $-0.328 * *$ & $-0.343 * * *$ & $-0.335 * * *$ \\
\hline & $(0.128)$ & $(0.119)$ & $(0.119)$ \\
\hline \multirow[t]{2}{*}{ FISC_TREAT_2014 } & $-0.184 *$ & $-0.159 *$ & $-0.172 * *$ \\
\hline & $(0.0980)$ & $(0.0847)$ & $(0.0842)$ \\
\hline \multirow[t]{2}{*}{ LEVERAGE } & -0.0706 & 0.0668 & 0.0466 \\
\hline & $(0.210)$ & $(0.243)$ & $(0.223)$ \\
\hline \multirow[t]{2}{*}{ FAMILY } & -0.00247 & 0.0410 & 0.0321 \\
\hline & $(0.0786)$ & $(0.0771)$ & $(0.0717)$ \\
\hline \multirow[t]{2}{*}{ FOREIGN } & -0.0658 & -0.0628 & -0.0726 \\
\hline & $(0.0800)$ & $(0.102)$ & $(0.0945)$ \\
\hline \multirow[t]{2}{*}{ STATE } & 0.0191 & -0.150 & -0.139 \\
\hline & $(0.102)$ & $(0.105)$ & $(0.0974)$ \\
\hline \multirow[t]{2}{*}{ BTP10Y_YIELD } & $2.609 * *$ & $2.782 * * *$ & $2.712 * * *$ \\
\hline & $(1.229)$ & $(1.005)$ & $(1.006)$ \\
\hline \multirow[t]{2}{*}{ Constant } & 0.130 & 0.0890 & 0.107 \\
\hline & $(0.169)$ & $(0.161)$ & $(0.144)$ \\
\hline Observations & 998 & 998 & 998 \\
\hline R-squared & 0.329 & 0.276 & 0.276 \\
\hline Number of COMPANY1 & & 82 & 82 \\
\hline
\end{tabular}

The model is run on a total of 998 observations, deriving from 82 companies, from 1987 to 2017. Analyzing the coefficients of the single variables it emerges that:

- $\quad$ The Voting Ratio variable has a positive impact on premium and is statistically significant. We, thus, find support for initially assuming that an increase in the number of saving shares versus common shares generates a larger separation between ownership and control that contributes to an increase in control premium.

- $\quad$ The $L 98$ variable has a negative and statistically significant impact on premium, which supports our notion that regulations introduced in 1998 in favor of a larger protection of minority shareholders (and as a result also stricter limits regarding the appropriation of private benefits for control) have determined a premium decrease.

- $\quad$ The Fiscal Treatment 2012 variable results statistically significant with a negative coefficient, in line with what assumed in the beginning. Since the passage of the withholding tax from $12.5 \%$ to $20 \%$ has produced a 
decrease in the differential between the two categories of shares, a decrease in the premium was to be expected. A possible explanation may lie in the fact that saving shares, by exploiting a financial privilege compared to common shares in presence of larger taxation regimes, have resulted more attractive in investors' eyes.

- The Fiscal Treatment 2014 variable is statistically significant with a negative coefficient, due to the increase of withholding tax from 20 to $26 \%$, effective since July 1, 2014.

- The leverage variable presents a positive coefficient but is not statistically significant, a result that is quite surprising. However, if we consider the pooling regression model, the coefficient of the variable assumes a negative value. The non-significance of the variable leaves a question mark on the sign of the estimated coefficient.

- The Family variable presents a positive coefficient both in the Fixed and Random model but is not statistically significant. The control of a private individual/family should decrease the possibility of a control change and this should lead to a decrease in the prices differentials of common shares versus saving shares. However, as highlighted by Caprio and Croci (2008), since the private/familiar control is the one that could lose more in terms of reputation, prestige and social/political relationships, the expectation of possible reactions to menaces of potential control changes ultimately leads to an increase of the price of common shares and, thus, the differential between the two classes of shares.

- $\quad$ The Foreign variable has a negative coefficient, to support the idea that, in case of control exerted by a foreign company/group, the price differential tends to decrease.

- The State variable presents a negative but not statistically significant coefficient, consistent with Zingales' findings (1994).

- The BTP10Y Yield variable is statistically significant with a positive coefficient, as initially expected. This positive relationship indicates that an increase of the yield on government bonds has a negative impact on saving shares price as an alternative investment option.

\section{Conclusions}

This paper tries to contribute to existing literature by focusing on a highly debated, but not extensively analysed topic, considering an extended time period covering thirty years (1987-2017). Furthermore, to our knowledge, this is the very first paper empirically analyzing the subject of control premium in the Italian context.

We do feel the need, however, to recognize limitations present in our work. Even though we base our analysis on 998 observations, our sample does not consider the prices of shares of different companies that, over the years, have issued saving shares. In addition, another factor to be considered in the valuation of a model is represented by the share price recording period and the consequent premium estimation. As a matter of fact, depending on the specific study considered, each author has adopted a specific methodology for computing premium, a potential explanation of contradicting findings on Voting Premium.

Our paper highlights how the introduction of new regulations in 2012, which moved the withholding tax on shares from $12.5 \%$ to $20 \%$, and further regulations in 2014 , with an additional increase from $20 \%$ to $26 \%$, have significantly contributed to a substantial premium reduction. The effect of such regulations needs to be examined within the macroeconomic setting that has distinguished the analysed period, particularly the last decade in the Stock Exchange, and within which the decision to raise the tax rate on financial yields needs to be contextualized. Furthermore, as it can be seen in our sample and Mediobanca's report, during the past years a constantly decreasing number of companies have resorted to the issue of saving shares as a financial instrument. The latter trend is also confirmed by Bigelli (2003) who claims that the main reason behind the decrease of saving shares is the consequence of the preference of big international investors to acquire "one share-one vote", in companies where the separation between ownership and control is limited.

In addition, there are also single factors that can change depending on the reference market, such as drops in interest rates and larger costs sustained by companies to face increased dividends paid to owners of saving shares. Another interesting motivation, observable particularly in the years following the economic crisis of 2007, is linked to the necessity of self-financing through the conversion of saving shares, where payment to shareholders of an amount in cash is required. Finally, in case of conversion, the same majority shareholders could be interested in purchasing the shares in order to reinforce their own position to the detriment of minority shareholders. Despite the aforementioned motivations, it is also true that in a period of heavy economic crisis distinguishing the past years, many companies of the examined sample have come across different financial instability periods, making it possible that saving shares issued assumes value because of their priority right to be refunded primarily in case of corporate liquidation, compared to common shares. This particular feature makes it possible that saving shares could, thus, result a financial instrument with larger guarantees in a turbulent economic and financial context. 
The paper has important managerial implications, as it has demonstrated how the introduction of new regulations in this field in 2012 has contributed to a substantial premium reduction, with important consequences on the corporate governance mechanisms of Italian firms. The results of the paper could be improved by further contributions aimed at examining the control premium trend in other European countries. The analyses would be particularly interesting if carried out by comparing the Italian situation to that of other countries with different taxation regulations. In fact, the findings of these paper are significantly affected the period in which the analysis has been carried out and especially since the decision to raise the tax rate on financial yields has been introduced.

\section{References}

Barclay, M., \& Holderness C. G. (1989). Private benefits from control of public corporations. Journal of Financial

$$
\text { Economics, 25, }
$$
371-395. https://EconPapers.repec.org/RePEc:eee:jfinec:v:25:y:1989:i:2:p:371-395

Barclay, M., \& Holderness, C. G. (1991). Negotiated Block Trades and Corporate Control. Journal of Finance, 25, 861-78. https://EconPapers.repec.org/RePEc:bla:jfinan:v:46:y:1991:i:3:p:861-78

Bigelli, M., \& Sapienza, E. (2003). Le azioni di risparmio e gli errori di misurazione del premio per il diritto di voto. Banca Impresa e Società, 22, 67-96.

Caprio, L., \& Croci, E. (2008). The determinants of the voting premium in Italy: The evidence from 1974 to 2003. Journal of Banking and Finance, 33, 2433-2443. 10.1016/j.jbankfin.2008.04.001

Caprio, L., Floreani, A., \& Radaelli, L. (1994). I trasferimenti del controllo di società quotate in Italia: un'analisi empirica dei prezzi e dei risultati per gli azionisti di minoranza. Finanza Imprese e Mercati, 3, 335-393.

Dyck, A., \& Zingales, L. (2004). Private benefits of control: An international comparison. The Journal of Finance, 59(2), 537-600. https://doi.org/10.1111/j.1540-6261.2004.00642.x

Linciano, N. (2002). Azioni di risparmio e valore del controllo: gli effetti della regolamentazione. Quaderni di Finanza.

Massari, M., Monge, V., \& Zanetti, L. (2006). Control premium in legally constrained markets for corporate control: the Italian case (1993-2003). Journal of Management and Governance, 10, 77-110.

Nicodano, G. (1998). Business groups, dual-class shares and the value of voting rights, Journal of Banking and Finance, 22, 1117-1137. https://doi.org/10.1016/S0378-4266(98)00051-X

Nicodano, G., \& Sembenelli, A. (2004). Private benefits, block transaction premiums and ownership structure. International Review of Financial Analysis, 13, 227-244. http://dx.doi.org/10.2139/ssrn.212248

Salvi, A. (2013). Premi per il controllo, metodo, misure, evidenze, Milano, Egea.

Venanzi, D. (2003). Struttura proprietaria, benefici privati del controllo e azioni di risparmio: il caso italiano. Finanza Marketing e Produzione, 3, 45-82.

Zingales, L. (1994). The value of the voting rights: A study of the Milan stock exchange experience, Review of Financial Studies, 7, 125-148. https://doi.org/10.1093/rfs/7.1.125

\section{Copyrights}

Copyright for this article is retained by the author(s), with first publication rights granted to the journal.

This is an open-access article distributed under the terms and conditions of the Creative Commons Attribution license (http://creativecommons.org/licenses/by/4.0/). 